\title{
"Let me tell you my life in a song" On Autobiography and Begging in Broadside Ballads of the Blind
}

\author{
Karin Strand \\ Svenskt visarkiv/Musikverket, Stockholm \\ Let me tell you my life in a song, \\ for when I remember time seems so long \\ My days are dark, and heavy everything \\ so I beg you: listen when I sing. ${ }^{1}$ \\ 1st stanza of "Lamentation of an invalid" by the former railway worker Karl Joelsson \\ (1870-1953) who lost his sight, his hearing and both hands as he was dynamiting \\ in America 1910.
}

\section{ABSTRACT IN ENGLISH}

What can street ballads tell us about the lives and realities of "common people", of experiences "from below"? This article discusses the functional aesthetics and social context of one particular genre that has circulated in ephemeral song prints (skillingtryck) in Sweden: beggar verses of the blind. For centuries, such songs were sold in the streets and at market places as a means for the blind to earn a living, and a major part of them tell the life story, the sad fate, of their protagonists. Many prints declare the genre of autobiography on their very front page, quite literally selling the story of the protagonist's life and addressing the audience's compassion. How, then, do these narratives relate to real life? How is individuality and authenticity expressed within a genre that to a large extent relies upon conventions and formulas? As is argued, songs of this kind are a suggestive source material of vernacular literacy, as well as of social and personal history from below. Simultaneously, the discourse is marked by and shaped in a dialogue with the sighted world's view of the blind. 


\section{ABSTRACT PA SVENSKA}

Vad kan skillingtryckens visor berätta om "vanligt folks" liv och verklighet? I denna artikel diskuteras en särskild genre som har spridits i enkla vistryck: tiggarverser av blinda, så kallade blindvisor. I Sverige har sådana visor sålts från 1600-talets slut fram till 1900-talets mitt på gator och marknader med syfte att bidra till den sinnesberövades försörjning. Merparten utger sig för att berätta huvudpersonens livshistoria och olycksöde, och många tryck deklarerar redan på framsidan att det är fråga om självbiografier. Det är alltså fråga om att bokstavligt talat sälja sin historia och att härigenom vädja till publikens medkänsla. Hur relaterar då dessa berättelser till det levda livet? Hur uttrycks individualitet och autenticitet i en genre som i hög utsträckning förlitar sig på konventioner och formler? I artikeln argumenteras för att dessa texter utgör ett suggestivt källmaterial såväl för vardagligt skriftbruk som för social- och personhistoria utifrån ett mikroperspektiv. Samtidigt är diskursen präglad av och formad i dialog med den seende världens syn på blinda.

Keywords: Broadside ballads, street literature, vernacular literacy, beggar verses

Literacy in the most traditional and obvious sense of the word-the ability to read and write-has up to modern times depended on eyesight, the ability to see. ${ }^{2}$ From the point of view of cultural heritage this visual precondition of literacy means that there are few textual sources that tell the stories and express personal experiences of blind people.

There is one striking exception, though: blind songs, that is: beggar verses of the blind. In Sweden such songs were made by or attributed to the blind themselves and were sold as ephemeral prints (skillingtryck) in the streets and at market places with the explicit purpose for the blind to earn a living. ${ }^{3}$ The songs are told in the first person and a major part of them tell the life story, the sad fate, of their protagonists. Spot checks in Danish and Norwegian national collections suggest that such beggar verses have been recurrent in other Nordic countries as well, but unfortunately there are no studies yet that could shed a comparative light. ${ }^{4}$

Songs of this kind, like other song prints on different matters, are preserved by libraries and folk music archives in Sweden. Considering their status as printed ephemera, commercial goods and manifestations of "low culture", the ambitions in collecting and cataloguing have been rather modest throughout history. The largest collection is to be found at The National Library of Sweden (Kungliga Biblioteket), which holds about 15000 unique skillingtryck of all different kinds. ${ }^{5}$ Several hundreds of these are blind songs, which still are only a small part of all prints that evidently have been circulating: blind songs for sale have been a diachronically and 
geographically widespread phenomenon. For my study of the genre, the prints at Kungliga biblioteket are the main source. ${ }^{6}$

This article aims to discuss some significant features of the blind songs depicted as self-narration and autobiographical texts. First, I will make some general points about the prints as a source material, then delineate a brief historical overview of constancies and changes within the genre from the earliest yet known print (published 1688) until the latest (dated 1961). Finally, I will take a closer look at a particular song in order to discuss narrative structure and currant tropes, and then end up by raising the question about the songs' dialogic dimensions. How do personal experiences of the blind relate to broader cultural contexts?

\section{PERSONAL RECORDS}

The ephemeral song prints could contain texts of all kinds, adapted from different sources (e.g. folk tradition, song collections, newspapers, follies) or written especially for the prints: there are hymns, celebration of the king, humorous songs, crime reports, love songs, war songs, poems, pamphlets and many other genres. ${ }^{7}$ The repertoire of topics, intentions and moral is as heterogeneous as the body of authors. There is also a great variation of realism and fiction, ranging from reports on social concerns via moralising, gossip or romanticised issues to sheer tales and fantasies. Apart from all their differences, the skillingtryck of different kinds share a significant basic precondition: they are commercial articles, made to address and interest a broad (that is: not primarily the wealthy and learned) audience of potential buyers. To this end, the producers deploy a wide range of appealing narrative strategies.

Though the prints lack music, the melodies are actually a key factor to the songs' popular attraction and use. Instead of notes, which very few could read anyway, many songs refer to another, presumably well-known song that the lyrics could be sung to. This is why printed song texts of this kind, a bit paradoxically as it seems, also are valuable source materials for historical musicologists: the references show which songs that were commonly known and used at certain times. ${ }^{8}$ The melody references in blind songs indicate that they rely on the same melody repertoire as many other broadsides on serious matters, that is: predominately hymns up to the mid-19th Century, after that. As the connection between text and tune.

Most lyrics in skillingtryck are published anonymously, even when the author is a well-known poet. ${ }^{9}$ The blind songs constitute a significant exception; the personal name is an essential label in presenting a (supposedly) authentic life story. To stress the discourse of self-narration, the genre of autobiography is often declared on the very front page. 


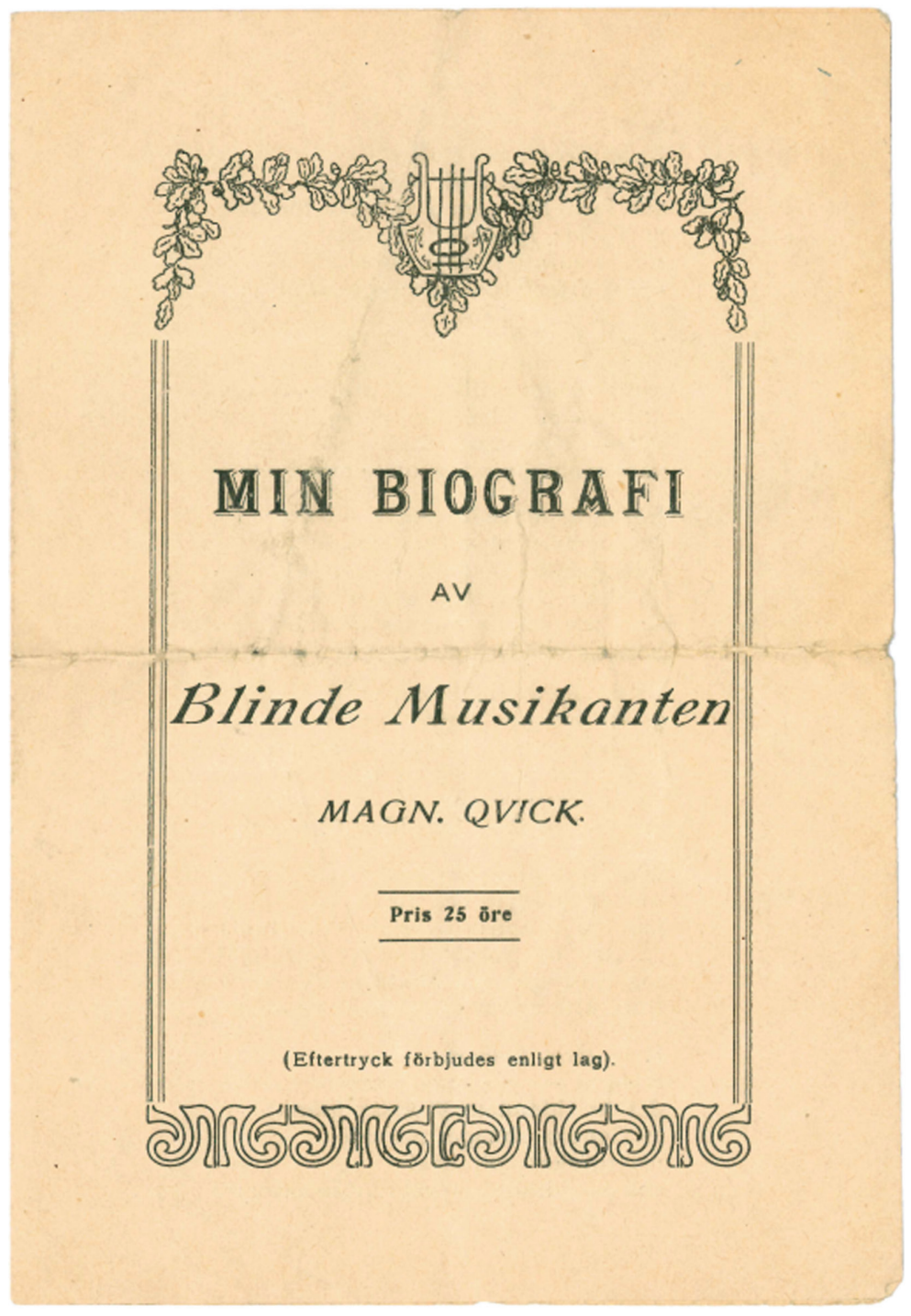

“Min biografi” by Magnus Qvick. Undated print, Svenskt visarkiv (KDBS 5). Photo: Aleksander Dybowski.

Consequently, the blind songs are formulated and marketed as true stories. But are they really; can we trust this claim? According to some exhaustive case studies of certain songs and the life of their protagonists, 
the answer is yes. ${ }^{10}$ We can probably be sure that some of the protagonists and stories are made up, but the vast majority of the personal names definitely do signify biographical persons, and in detail or in general terms, the songs tell (selected parts of) their particular life story. Moreover, the songs were printed on the initiative of the protagonist and sold by himor herself. As gender balance is concerned, there are almost only male performers within the genre, but there are some interesting examples of blind women who tell their story. ${ }^{11}$

There are, in other words, obvious reasons for considering blind songs as autobiographical texts, related to other forms of vernacular and popular life-writings. ${ }^{12}$ As with other forms of autobiography, the narrative of blind songs is of course no "pure", objective version of the life lived. The genre is a distinctive merging of social and aesthetical discourse, relying on skills which, crudely put, make a sad life worth buying. The instrumental aim is to appeal to the audience's compassion and willingness to pay by, quite literally, selling the story of one's life.

\section{DIACHRONIC TENDENCY}

The history of printed blind songs goes back to the late 17th century and continues well up to the mid-20th century in Sweden. During this period of almost three centuries the songs have undergone essential changes in form and content, as have the society they are part of and the audience they address. The most significant diachronic tendency within the genre is a shift from religiously tinged lamentations towards socially oriented texts of explicit begging.

In songs from the 18th and early 19th century the disability is explained and thematised in terms of a God's probation. The blind person refers to her- or himself as a living example of God's power and mercy, and as a mirror for the sighted world that should appreciate its senses: "what I am today, you could be tomorrow".

There are, however, variations as to what degree the blind person positions him- or herself as the textual subject. Not all lyrics thematise the fate of the blind in a direct way; some report on sensational news and some are general religious-edifying reflections. Whatever manifest issue of song and print, however, the author's disability is always declared as an epithet to the name-a byname resonating the implied misfortune.

By the middle of the 19th century there is a materialistic and subjective turn in the blind songs. The social and economic tribulations, the crude consequences of the loss of sight, are increasingly foregrounded, and the protagonist tells the story of his/her specific life. This change, 
from religious and general to profane and personal narration, can be seen both in the light of secularisation and of a gradual shift within writing conventions towards subjectivity and a modern self. ${ }^{13}$

The increasing frankness may also, interestingly enough, mirror an actual legal change: the abolishment of the "beggary charter" (tiggarstadgan) in 1847. The beggary charter was an exception in the general prohibition of beggary, an exemption that permitted beggary in the person's own home district. As this exception was taken away, beggary was-officially, anyway-prohibited everywhere in society. As an alternative, the making and selling of song prints would make a formally legal way to earn a living. From the point of view of the official society and of philanthropists of the time, the song trade, however, was constantly discouraged as a form of "hidden beggary".

\section{REMARKABLE DOCUMENTS}

As historical source material, there are some characteristics of blind songs that are particularly interesting. Representing voices from the outside or below, they are something as rare as testimonies of the visually impaired themselves. Evidently, there could be other (sighted) people involved in the very practices of authoring, writing down and printing the songs. As my case studies have shown, the blind could dictate the verses so someone who wrote them down, or get help by a poetically skilled friend, a "ghost writer", to write a song after his or her story. ${ }^{15}$ In some cases, lyrics from other blind songs were simply reused and "re-personalised" with the change of name and personal details. ${ }^{16}$ The life story, then, can still be true in a general sense, but the phenomenon undoubtedly brings the issue of authenticity to a head.

To different degrees, then, we can account for each blind song to represent an actual person's experience; an evidence of the exposed. This makes the songs a unique piece of cultural heritage. As we know, there is no shortage of "Blind men" as motifs within cultural history, where we usually meet them symbolically charged, as emblematic characters personified as bards, prophets, beggars and tragic heroes. Several scholars have studied the use and meaning of blindness and blind people within western literature. Edward Larrissy, for example, demonstrates how the enigma of the blind was especially productive within the literature of the romantic period, working as symbols of lost vision in the dawning modernity. ${ }^{17}$

In his study The melodramatic imagination, Peter Brooks argues that different literary genres have their corresponding sensory deprivations. ${ }^{18}$ 
In comedy, deafness is recurrent, which could be seen in relation to the genre's preoccupation with problems of communication, misunderstandings and their consequences. For melodrama, muteness is the preferred handicap, connected to the melodramatic urge for expression. Blindness then, according to this scheme, is the disablement of tragedy, a genre devoted to issues of (false or too late) insight and illumination. Brooks argues that the very presence of the sensory deprived evokes the extremism and hyperbole of ethical conflict and manichaeistic struggle. ${ }^{19}$ As opposed to the use of the Blind as elevated motives, protagonists of blind songs are thus social subjects, speaking of true, crude experiences.

A significant feature of the song genre and print type per se is their long persistence into modern times. Beggar verses of the blind, as well as of the crippled and unemployed, continue to be produced and sold long after the decline of other broadsides in Sweden which occurs in the 1920s. An inventory of preserved prints suggests that the publishing of beggar verses peaks in the interwar period, but they kept on circulating well after that. The youngest prints yet registered date from the 1960s, and a field recording made in 1973 documents a blind market singer who at the time was still selling the song print about his life and misfortune. ${ }^{20}$

What is also intriguing about blind songs, however, is that this diachronically and geographically well-spread phenomenon has left almost no trace in Swedish folk song tradition; neither in hand-written song books nor in sound recordings of singers. Obviously, the beggar verses were article bought out of compassion rather than with an interest in learning and incorporating them as part of a personal repertoire.

There is one striking exception, though; the song of the former railway worker Viktor Lindroth (1876-1953). ${ }^{21}$ Lindroth had lost his sight, and most of his left hand, in 1901 as he was dynamiting rocks. About a year after the accident, he asked a skilled mate to help him write a song about his misfortune, and had it printed. Unlike most other blind song sellers of the time, however, Lindroth didn't go to market places to sell his song. Instead, he went to railway working plants around the country and offered his story to former fellow workers; a clientele that certainly could sympathize and identify with his fate. As is confirmed by Lindroth's stepson, who, as a child, sometimes came along these trips, the navvies happily bought Lindroth's song. ${ }^{22}$

The guild of navvies has a strong tradition of singing during work, and they were also a mobile group of workers. Lindroth's song was soon picked up as part of their repertoire and was eventually spread throughout the country. From the song print via oral tradition, it has been reprinted in several folk song collections as late as in the 1980ies. ${ }^{23}$ This is the only example of a Swedish blind song that got a life in tradition, outside the print. 


\section{GERTIFICATIONS OF AUTHENTICITY}

What is at stake in the trade of blind songs is the issue of credibility, a (presumed) direct relationship between the lyrics and the life it describes. The audience must, simply put, be assured that the personal story is true.

To that end, there is a range of different markers of authenticity used in the prints and songs. Most obvious, there is the naming of the protagonist and detailed information about the disease or the accident that made the person blind. As soon as it was technically possible, there is also the use of photos on the front page, pictures that visually verify the person's sad state.

Most decisive is of course the authenticity of the handicap itself, the obstacle that prevents the person to support himself "from honourable labour". The suspicion that song selling might just be a way of avoiding social control and hard physical work is something that the protagonists often explicitly forestall and refute in their prints. ${ }^{24}$ To attest the truth of the disablement, several prints contain copies of medical certificates.

A more indirect certificate of authenticity concerns the standard of aesthetical craft; the "un-professionalism" of the lyrical work. In many texts, the authors self-critically comment on their deficiencies as poets, and on the simplicity and inferiority of their performance. This does not only seem to be a gesture of humbleness; the foregrounding of the amateur position also underlines the distress behind the article. As opposed to poets, the authors of blind songs are not driven by an inner urge and inspiration, but rather by outer constraint.

\section{"MY BIOGRAPHY”}

The typical blind song from the latter half of the 19th century is a versified little autobiography, put in the first person singular. Schematically, the narration follows a similar pattern: there is a set of tableaux representing stages on the path leading to the distressed present, with some variations in order and emphasis. The slightly paradoxical state of the genre is thus that the songs express individual fates, relying on a shared repertoire of formulas.

As touched upon, the songs can be related to other autobiographical genres, popular as well as high cultural. Despite the absence of artistic pretentions within the blind songs there are, for instance, fundamental correspondences between them and the literary autobiography. A basic common denominator is the quest of uniting the past and the present. 


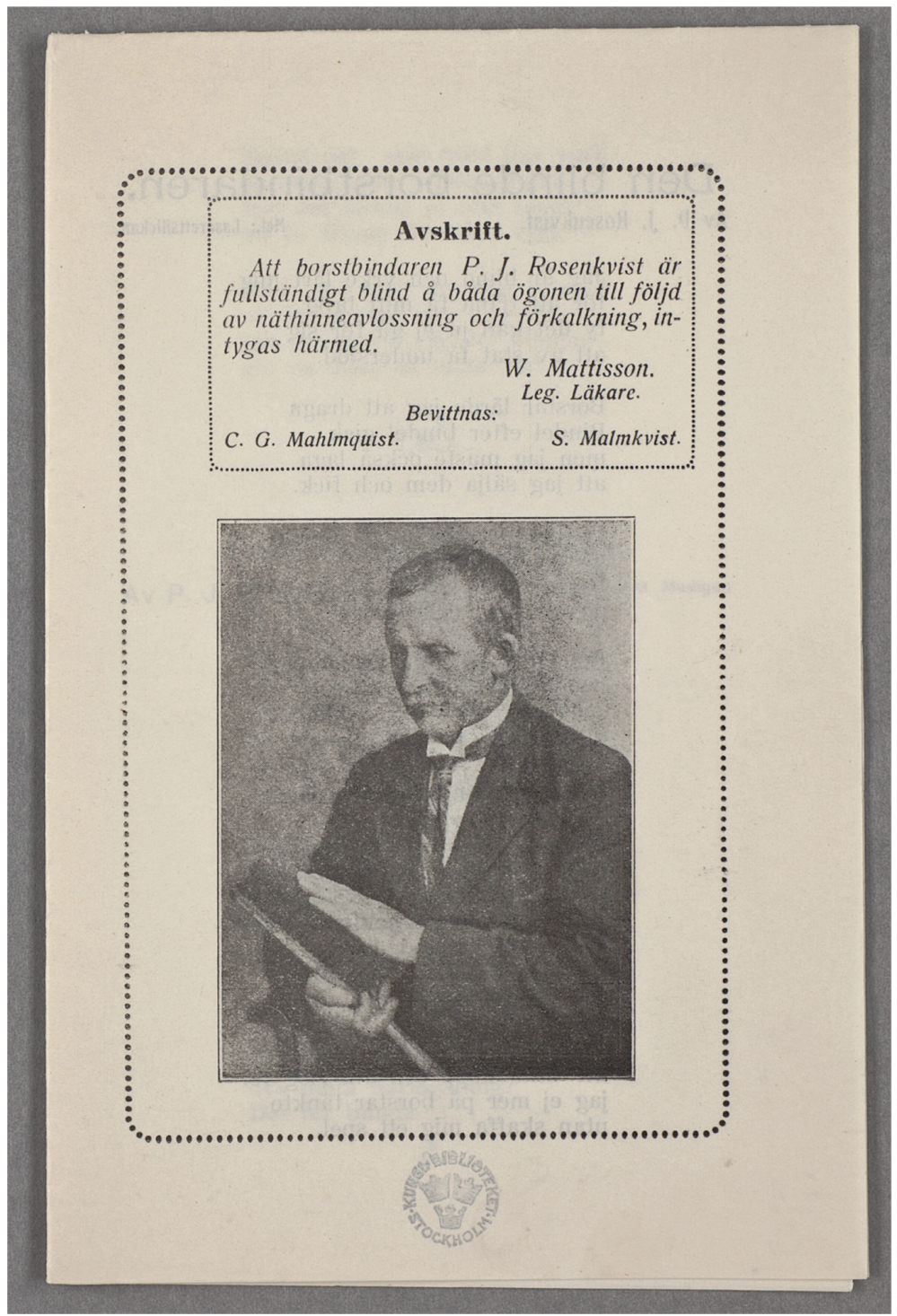

Attested copy of medical certificate on front page of P. J. Rosenkvist's print, published in Eslöv 1926. Kungliga biblioteket. Photo: Jens Östman.

Schematically, an autobiography consists of a narrator here and now who describes the development of a protagonist there and then, a person with the same name as the narrator. ${ }^{25}$ According to the convention, the 
protagonist will be transported from the past to the present in such a way that he or she merges into the contemporary person. This coalescence requires a theory of development, or at least a transformation. To illustrate the blind song's way of doing this, and to discuss some of the commonplaces of the genre, I here refer to a song at length: "Song by J.E. Haraldsson", printed in 1925: ${ }^{26}$

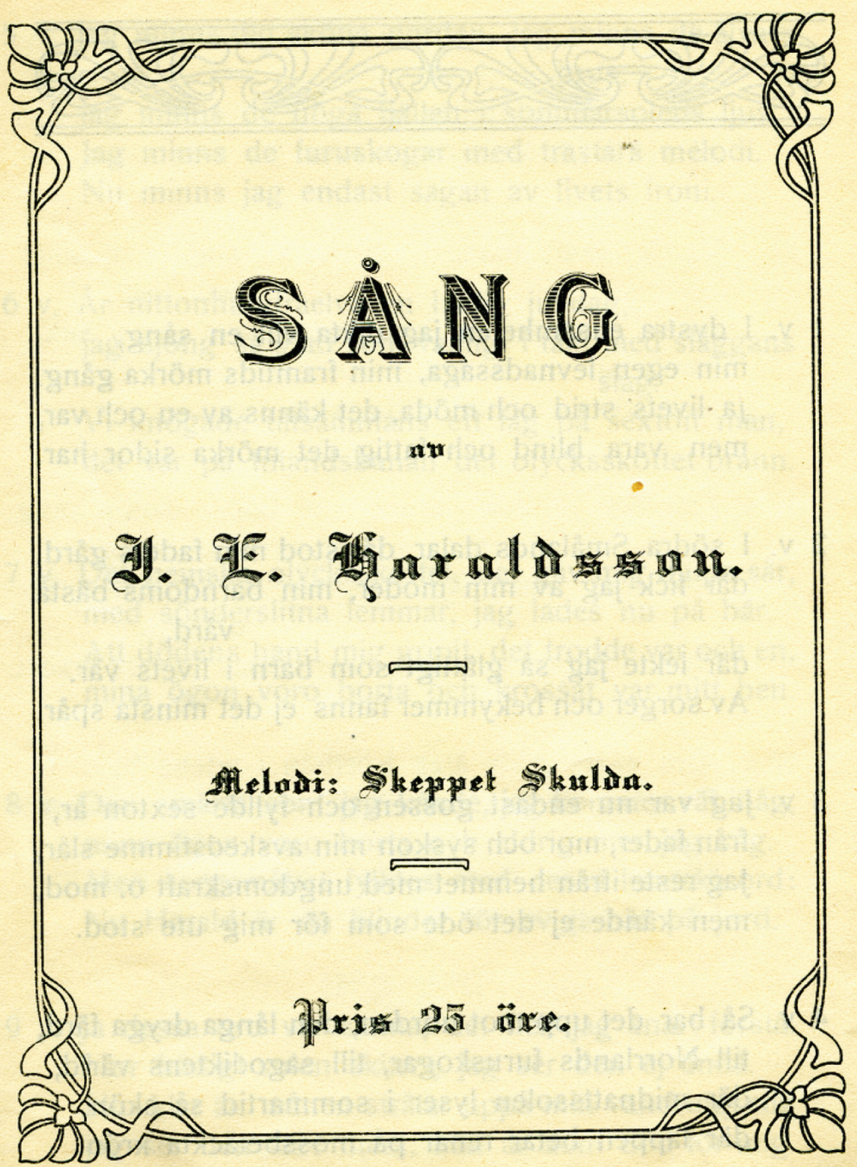

Front page of "Sång av J.E. Haraldsson", first printed in Linköping 1925. Svenskt visarkiv, KDBS 64. Photo: Roger Bergner. 


\section{Song by J.E. Haraldsson}

1. In my dismal loneliness I will write a song, My own life story, the dark road to my future. Yes, the struggles and pains of life are felt by everyone, but to be blind and poor, that has its dark side.

2. In the valleys of "Småland" my father's farm was placed, There I received from my mother the best care during my childhood, there-as a child-I played so joyfully in the spring of life. There was no trace of sorrows and worries, not the least.

3. I was just a boy, sixteen years old, when I left my father, mother, sister and brother. I travelled from there with youthful strength and energy, But did not know the fate out there, awaiting me.

4. I went off to the North, the long, hard journey to the pine forests of "Norrland", to the world of fairy poems, where the midnight sun is shining beautifully in summer, where the Saami let their reindeer graze on moss-covered crests.

5. I remember you, beautiful North, I remember the roar of the rivers, I remember the high mountains, lit by the summer sun, I remember the pine forests with tunes of thrushes.

Now, I only remember the saga of the irony of life.

6. In 1911, on a wonderful day in July as usual I sang so happily, in pace with the hammer blows.

We worked together, a team of sixteen men, It was on the railway "Inlandsbanan" the disastrous shot occurred.

7. The dreadful shot, it gave me deep wounds;

With torn limbs I was laid on a stretcher.

Everyone thought I was caught by the hand of Death, My eyes were gone, and my leg was crushed.

8. The pain I felt, I can well recall, my eyes were gone, and never more I saw.

But the measure of sorrow was filled with these awful words:

"Now Harald, you are for ever blind here on earth!"

9. Yes, these words were true, I soon came to understand.

How lovely the sun shines, I will never see. 
However clearly the moon shines on my way,

I will never see it-it is now dead for me.

10. Now, when I recall how everything has changed:

How thorny my dark, long path has become,

my youthful strength is gone-whatever it once was,

And all joy I have expected is gone.

11. Why do so many have to drink so deeply from the cup of pain, why shall I wander like this like a hunted falcon, because I am poor and have no means.

My power to work is gone-that was my only capital.

12. Thank you all friends who buy this song,

I cannot work, and the days are long!

But if you have some coins, then you are not afraid

of the ghost of poverty, raising itself so cheekily.

13. But slowly the years glide away in the sea of time.

Once also I can lay down my heavy wandering stick, and when the evening bells invite us to our fathers' peace, then also I will rest in eternity.

The song begins by introducing the very act of singing with promises of a true story: "In my dismal loneliness I will sing a song/the saga of my own life, my dark way to the future". After having established the situation of the performance in a present here and now, a memory of a happy "before" often follows. As in the second stanza: "In the valleys of South Småland, there stood my father's farm...". In remembering and describing the idyllic childhood, visual impressions are often referred-even in songs where the protagonists lost their sight as a small baby can visual memories be vividly described.

Within Western autobiography, emphasized turning points are almost compulsory, events that, step by step, take the protagonist from what he/ she was to what he/she is now. The turning points of the high literary autobiography are usually urged on by the conviction or thought of the protagonist, as an expression of the subject's intentional power. As a contrast, the decisive moment, as well as the very premise, for the blind song is the loss of eye-sight, a tragic accident that hits, far from the power of will. In song prints from the 17th and 18th century, this event is spoken of in terms of a God's punishment or probation. In this and other beggar songs from the 20th century, however, the concrete circumstances take pride of place: the accidents or diseases that have ruined the basic 
preconditions for life and work forever. In our example, stanzas 6-8 deal with the accident, and here we even get to hear the doctor's words as the result of the examination, the doom, was declared: "Now Harald, you are for-ever blind here on earth!"

The existential dimension of suddenly having lost one of one's senses is also often thematised. In this example, the lamentation is particularly clear in the stanzas 9-11. Usually the songs end in a "here and now"; in analogy with the introduction stanza we are back in the timescape of the performance where the song is about to be ended. Having finished the story of his life the protagonist turns to the reader or listener and appeals for empathy, as in the 12th stanza: "Thank you all friends who buy this song...”

As far as the language is concerned, the whole tradition of blind songs is characterized by tropes that can be perceived both literally and metaphorically; a double exposure of meaning. At the core of the genre we, quite naturally, find expressions dealing with sight, light and darkness. Examples from other songs are references to an unhappy childhood in terms of "never having experienced the light", or descriptions of helplessness as "to stumble my whole life in darkness-not knowing where to go". Kind-hearted friends can be called "supports" and be praised for "spreading light into my world".

A recurrent image, especially common in the older, spiritually tinged, songs, is that the blind person works as a mirror for the seeing world. The idea of the blind person as a looking glass comprises a test of people's empathy as well as a vicarious suffering and a warning reminder of God's power. The mirror metaphor, then, exhorts the audience to reflect.

\section{THE GAZE OF THE SIGHTED}

Blind songs in a proper sense are songs written by or attributed to visually impaired persons, and that tell the story of their misfortune. There are, however, some seemingly related songs that depict a fictive blind character, or are dedicated to a real blind person. These kinds of "blind songs" are written by non-blind authors who use the sensory deprived to depict other versions of blind experience than the tragic. In such texts, there is a tendency to sentimentalize and mystify the protagonist: the blind is not only presented as fully satisfied with his fate, but is also well aware of his special gifts.

The song or poem "The Blind" could serve as an example of the kind written by the poet, song writer and bookseller J. H. Chronwall who also was a well-known agent on the market of Swedish song prints in the early 
20th century. ${ }^{27}$ The verse was first published in 1901 and is said to be "dedicated to the blind Fromell in Sala". To all appearances this Fromell is an actual person, a blind basket-maker who was born in $1848 .{ }^{28} \mathrm{He}$ was thus 53 years old at the time when Chronwall gives him the following voice: ${ }^{29}$

\section{Den blinde:}

Jag föddes blind. Den rika, sköna naturens prakt har jag ej sett; likväl dess höghet kan jag röna med det förstånd mig Skaparn gett. En inre, herrlig verld jag sluter i mitt på minnen rika bröst; af denna inre verld jag njuter, och detta är min enda tröst.

I mörker går min lefnadsbana; men evigt klar min sjål dock år. Hrad andra se, det kan jag ana. Om många ting jag kunskap bär. Jag med inbillningens fürmåga mig jord och himlar skapa kan. $\mathrm{Pådetta} \mathrm{sättet} \mathrm{vill} \mathrm{jag} \mathrm{våga:}$

jag săll är mer än mången an'n.

$$
\text { Sången författad af } \overline{\text { Fromell } i \text { Sala. }} \text { och tillegnad blinde }
$$

“The blind", first printed in 1901. Svenskt visarkiv, OD 4:19:1. Photo: Roger Bergner

\section{The blind}

1. I was born blind. The rich and green grandeur of nature I have never seen; still I can experience its sublimity with the reason our Creator has given me. I will hide this inner world, full of exuberance, in my breast, so full of remembrance; of this inner world I have more than satisfaction; and this is my only consolation. 
2. Through the dark goes my career;

but my soul is always clear.

what others see, I can just feel.

I know a lot of things that are real.

With imagination as an art

world and heavens I can chart.

In this way I will venture

To say I'm happier than any other creature.

Plain to see, the poem is not a depiction of the blind Fromell, but rather an idealized view of him, presented by the seeing author. The blind is described as a self conscious person with a rich inner life-not despite of but rather because of his physical limitations. He lacks the ability of seeing, but enjoys the gift of an alternative clairvoyance. The blind person is given both mythical and mystical dimensions-the world may be hidden from his sight, but he possesses and creates worlds that no one else can share. Gifted with an exceptional imagination, the blind man considers himself to be more favoured than most other people.

\section{DIALOGIC DIMENSIONS}

Such notions of the compensating abilities of the blind as well as their assumed natural gift for fantasy and creation, were current ideas in educated literature of the 19th century. As touched upon, blindness was one of the most significant topoi in the era of romanticism, both in literary representations and philosophical discussions in Europe. In particular, as Edward Larrissy has shown, there is the antique motif of a blind poet or prophet, a visionary, whose vision, having lost the presence of this world, is directed beyond it, towards the spiritual. ${ }^{30}$ Within their time context, the blind characters of Romanticism symbolize the innocence and visionary spontaneity that are at risk of getting lost in the rise of modernity.

The blind as an elevated symbol, and thus not only as a pitiable social figure, is actually a connotation latent in the songs of the blind protagonists that we have been discussing here as well. Starting with the tropes of light and darkness, insight and clairvoyance, they allow for existential and imaginary meanings. Moreover, there are instances when the narrator refers to mythical images from the realm of educated literature in his self-representation. So is the case in a song from 1903 by the blind singer and song trader Hjalmar Wiede. ${ }^{31}$ In his song "The blind" Wiede uses the simile that he is wandering "like an antique minstrel [...] with my song from door to door". 
Admittedly, such explicit references are not common, but they do indicate that the subject of the song cannot be detached from "the blind" as an emblematic stereotype, neither for the seeing audience nor for the song maker who calls for its attention. As a rhetorical act, the blind song must reach out to potential helpers and thus relate to their views and fantasies. Taking this dialogic dimension into account, the blind songs tell us just as much about the needs of the sighted world as of the social reality of the blind.

\section{WORKS CITED}

\section{Literature}

Brooks, Peter. The Melodramatic Imagination: Balzac, Henry James, Melodrama, and the Mode of Excess. New Haven: Yale University Press, 1995 [1976].

Bruner, Jerome. In Search of Mind. Essays in Autobiography. New York: Harper \& Row, 1983.

Danielson, Eva. "'Visan författad, satt och gjuten af Chronwall'. Om Svenska Visförlaget och bröderna Chronwall”. I: Sumlen. Årsbok för vis- och folkmusikforskning. Stockholm: Samfundet för visforskning, 1981. 110-146.

Edlund, Ann-Catrine. Ett rum för dagen: en studie av två kvinnors dagboksskrivande i norrländsk jordbruksmiljö. Umeå: Kulturgräns norr, 2007. Kulturens frontlinjer 53.

Edlund, Ann-Catrine. "The Song Book and the Peasant Diary as Participants in the Construction of the Modern Self." Eds. Ashplant Edlund and Kuismin. Reading and Writing from Below: Exploring the Margins of Modernity. Umeå: Umeå University and Royal Skyttean Society, 2016. Northern studies monographs 4, Vardagligt skriftbruk 4. 77-96.

Förhammar, Staffan. "Organiserad filantropi i Sverige under 1800-talets senare del. Exemplet hjälp till handikappade.” I: Scandia. Tidskrift för historisk forskning 61:2 (1995): 159-196. Lund: Scandia.

Gillgren, Sten and Hjalmar Wide. Hjalmar Wide. En föregångsman inom blindrörelsen. Levnadsbeskrivning med dokumentation av utgivna skrifter. Sundsvall: Kulturmagasinet, 1995.

Jersild, Margareta. Skillingtryck. Studier $i$ svensk folklig vissång före 1800. Stockholm: Svenskt visarkiv, 1975. Diss.

Johansson, Torbjörn. Halländska visor och andra sånger som sjungits $i$ Halland. Halmstad: Spektra, 1984.

Larrissy, Edward. The Blind and Blindness in Literature of the Romantic Period. Edinburgh: Edinburgh University Press, 2007.

Liljewall, Britt. Själuskriuna liv. Studier i äldre folkliga levnadsminnen. Stockholm: Nordiska museets förlag, 2001.

Nilsson, Anna. Lyckans betydelse. Sekularisering, sensibilisering och individualisering $i$ svenska skillingtryck 1750-1850. Höör: Agering, 2012. Diss.

Olrog, Ulf Peder. Studier i folkets visor. Utgivna och kommenterade av Mathias Boström, Märta Ramsten och Karin Strand. Stockholm: Svenskt visarkiv i samarbete med Samfundet för visforskning, 2011 [1951]. (Skrifter utgivna av Svenskt visarkiv 31).

Olsson, Claes G. Omsorg och kontroll. En handikapphistorisk studie 1750-1930. Umeå: Umeå Universitet, Institutionen för kultur och medier, 2010. Diss.

Shepard, Leslie. The history of street literature. The story of broadside ballads, chapbooks, proclamations, news-sheets, elections bills, tracts, pamphlets, cocks, catchpennies, and other ephemera. Detroit: Singing Tree P, 1973. 
Strand, Karin. "Den blindas sång. Om visor i marginalen av marginalen." In: Noterat 21. Tema: musik, dans och genus. Stockholm: Svenskt visarkiv, 2014. 25-44.

Strand, Karin. Brott, tiggeri och brännvinets fördärv. Studier $i$ socialt orienterade visor $i$ skillingtryck. Möklinta: Gidlund, 2016.

Strand, Karin. "Street ballads spreading the word. The case of "The two maids that married each other'." Eds. Ann-Catrine Edlund, T. G. Ashplant and Anna Kuismin. Reading and writing from below. Exploring the margins of modernity. Umeå: Umeå University and Royal Skyttean Society, 2016. Northern studies monographs 4, Vardagligt skriftbruk 4. 149-165.

Sonnbäck, Kerstin. Gick jag ut $i$ solegång och andra visor från Folkarebygden. Falun: Dalarnas museum, 1984.

\section{Song prints}

* Kungliga biblioteket, the chap book collection:

Blind songs filed under the sigla $\mathrm{H}$ and $\mathrm{E}$

Beggar verses in the collection Okat. Sv. Tiggarverser 1850-1961

*Svenskt visarkiv:

Song prints filed under the sigla A, GS, KDBS and OD

Archival sources, Svenskt visarkiv

\section{Sound recording}

SVA BA 1927 ("Penten" Olsson recorded by Märta Ramsten at Rabbaldshede market, Bohuslän 1973-04-26), Svenskt visarkiv's sound collection.

\section{Manuscript}

h1483:16 (Letter from Fredrik Lindqvist to folk song researcher Lennart Kjellgren, dated 1984-06-13), Svenskt visarkiv's manuscript collection.

\section{ABOUT THE AUTHOR}

Karin Strand has a PhD in comparative literature and is Deputy Head of Archives at Svenskt visarkiv (Centre for Swedish Folk Music and Jazz Research), Musikverket (Swedish Performing Arts Agency) in Stockholm. Strand just finished a research project about street ballads and song prints on social matters, presented in the book Brott, tiggeri och brännvinets fördärv. Studier $i$ socialt orienterade visor $i$ skillingtryck (2016). At present, she is studying the representation of female criminals in street ballads. During 2018-2019 Strand holds a professor II position within the research and digitization project Norwegian Broadside ballads 1550-1950: recovering a cultural heritage, led by Siv Gøril Brandtzæg, and financed by the Norwegian Research Council (project number 274952). 


\section{NOTES}

1 Translation: Johnny Strand.

2 The article is based upon a paper held at the 4th IABA Europe Conference in Funchal 27-29 May 2015: Dialogical Dimensions in Narrating Lives and Life Writing.

3 Similar prints and print types have been common all over Europe from early modern time up to the 20th century under different names. In English: broadsides and chap books, in German: Flugblätter, for example. C. f. Shepard, Leslie, The History of Street Literature. The Story of Broadside Ballads, Chapbooks, Proclamations, News-sheets, Elections Bills, Tracts, Pamphlets, Cocks, Catchpennies, and Other Ephemera. Detroit: Singing Tree P, 1973.

4 Spot checks made at Dansk folkemindessamling, Palsbo collection (Kongl. Biblioteket) and Norsk visearkiv collection (Nasjonalbiblioteket).

5 On collections and ordering principles of skillingtryck in Sweden, see Strand, Karin Brott, tiggeri och brännvinets fördärv. Studier $i$ socialt orienterade visor $i$ skillingtryck. Möklinta: Gidlund, 2016 (Pp. 21-24).

6 The study of blind songs is one out of three parts in my book on street ballads on social matters (Strand 2016, Pp. 27-115).

7 For discussions on crime songs, see Strand, "Street ballads spreading the word. The case of 'The two maids that married each other'." In: Edlund et al. (eds): Reading and writing from below. Exploring the margins of modernity. Umeå: Umeå University and Royal Skyttean Society, 2016. Northern studies monographs 4, Vardagligt skriftbruk 4. (Pp 149-165).

8 C. f. Jersild, Margareta, Skillingtryck. Studier $i$ svensk folklig vissång före 1800. Stockholm: Svenskt visarkiv, 1975. Diss.

9 For a record of known poets represented in Swedish broadsides, see Olrog, Ulf Peder, Studier $i$ folkets visor. Utgivna och kommenterade av Mathias Boström, Märta Ramsten och Karin Strand. Stockholm: Svenskt visarkiv i samarbete med Samfundet för visforskning, 2011. Skrifter utgivna av Svenskt visarkiv 31. (Pp. 143-167).

10 See f. ex. the cases of Karl Joelsson and Viktor Lindroth in Strand 2016 (Brott, tiggeri...), pp. 94-112).

11 C.f. Strand, "Den blindas sång. Om visor i marginalen av marginalen." In: Noterat 21. Tema: musik, dans och genus. Stockholm: Svenskt visarkiv, 2014. (Pp. 25-44).

12 See f. ex. Britt Liljewall's (2001) comprehensive study of "self-written lives" and Ann-Catrine Edlund's (2007; 2016) research on peasant diaries and hand written song books.

13 C. f. Nilsson, Anna. Lyckans betydelse. Sekularisering, sensibilisering och individualisering $i$ svenska skillingtryck 1750-1850. Höör: Agering, 2012, p. 207.

14 Förhammar, Staffan, "Organiserad filantropi i Sverige under 1800-talets senare del. Exemplet hjälp till handikappade”. In: Scandia. Tidskrift för historisk forskning. 61:2. Lund: Scandia, 1995 (Pp. 159-196). Olsson, Claes G, Omsorg och kontroll. En handikapphistorisk studie 1750-1930. Umeå: Umeå Universitet, Institutionen för kultur och medier, 2010 (passim).

15 Strand 2016 (Brott, tiggeri...), p. 36.

16 Strand 2016 (Brott, tiggeri...), p. 36.

17 Larrissy, Edward, The Blind and Blindness in Literature of the Romantic Period. Edinburgh: Edinburgh University Press, 2007.

18 Brooks, Peter, The Melodramatic Imagination: Balzac, Henry James, Melodrama, and the Mode of Excess. New Haven/London, 1995 [1976], p. 57.

19 Brooks, p. 56.

20 Sound recording SVA BA 1927, song print KDBS 59 (both at Svenskt visarkiv).

21 On Lindroth's life and song, c.f. Strand 2016 (Brott, tiggeri...), pp. 101-112.

22 Letter from Fredrik Lindqvist to folk song researcher Lennart Kjellgren, dated 1984-0613. Manuscript in Svenskt visarkiv, acc.no h1483:16. 
23 See f. ex. Johansson (1984) and Sonnbäck (1984).

24 Strand 2016 (Brott, tiggeri...), pp. $75 f$.

25 Bruner, Jerome 1983. In Search of Mind. Essays in Autobiography. New York: Harper \& Row, p. 27.

26 Translation: Birgit Sawyer.

27 Danielson, "Visan författad, satt och gjuten af Chronwall'. Om Svenska Visförlaget och bröderna Chronwall”. In: Sumlen. Årsbok för vis- och folkmusikforskning. Stockholm: Samfundet för visforskning, 1981 (Pp. 110-146).

28 Personal data on Fromell in Lars Erik Ledungs notes in his transcript of the song (copy in Svenskt visarkiv).

29 Translation: Birgit Sawyer.

30 Larrissy 2007.

31 Gillgren, Sten \& Hjalmar Wide, Hjalmar Wide. En föregångsman inom blindrörelsen. Leunadsbeskrivning med dokumentation av utgivna skrifter. Sundsvall: Kulturmagasinet, 1995. 